C O N T R I B U I Ç Ã O E S P E C I A L

\title{
CANONS AND COLONIES: THE GLOBAL TRAJECTORY OF SOCIOLOGY
}

Cânones e colônias: a trajetória global da sociologia

Cánones y colonias: la trayectoria global de la sociología

RAEWYN CONNELL ${ }^{*}$

DOI: http://dx.doi.org/10.1590/S2178-14942019000200002

\footnotetext{
'University of Sydney, Sydney, Australia.

* Professor Emerita, University of Sydney, and Life Member of the National Tertiary Education Union. She has taught in several countries and is a widely-cited sociological researcher. Her recent books include The Good University; Gênero em termos reais; Southern Theory; and Gender in World Perspective (with Rebecca Pearse). Her work has been translated into nineteen languages. Raewyn has been active in the labour movement, the peace movement, and work for gender equality. (raewyn.connell@sydney.edu.au) ORCID iD: http://orcid.org/0000-0001-8001-2375
}

Recebido em 10 de março de 2019 e aprovado para publicação em 17 de junho de 2019. 


\begin{abstract}
The history of sociology as a field of knowledge, especially in the English-speaking world, has been obscured by the discipline's own origin myth in the form of a canon of "classical theory" concerned with European modernity. Sociology was involved in the world of empire from the start. Making the canon more inclusive, in gender, race, and even global terms, is not an adequate correction. Important types of social knowledge, including movementbased and indigenous knowledges, resist canonization. The turn towards decolonial and Southern perspectives, now happening across the social sciences, opens up new perspectives on the history of knowledge. These can be linked with a more sophisticated view of the collective production of knowledge by the workforces that are increasingly, though unequally, interacting. Potentials for a more effectively engaged sociology emerge.
\end{abstract}

PALAVRAS-CHAVE: History of Sociology; canon formation; classical theory; colonialism; Global South.

\title{
RESUMO
}

A história da sociologia como um campo de conhecimento, especialmente no mundo de língua inglesa, foi obscurecida pelo próprio mito de origem da disciplina na forma de um cânone da "teoria clássica" relacionada à modernidade europeia. A sociologia está envolvida no mundo do império desde o início. Tornar o cânone mais inclusivo, em termos de gênero, raça e mesmo globais, não é uma correção adequada. Importantes tipos de conhecimento social, incluindo conhecimentos baseados em movimentos e indígenas, resistem à canonização. $\mathrm{A}$ virada para as perspectivas decolonial e meridional, agora acontecendo por meio das ciências sociais, abre novas possibilidades sobre a história do conhecimento, que podem estar ligadas a uma visão mais sofisticada da produção coletiva de conhecimento pelas forças de trabalho que estão interagindo cada vez mais, embora de forma desigual. Potenciais para uma sociologia mais engajada têm emergido.

PALAVRAS-CHAVE: História da Sociologia; formação de cânones; teoria clássica; colonialismo; Sul global.

\section{RESUMEN}

La historia de la sociología como un campo de conocimiento, especialmente en el mundo de habla inglesa, ha sido oscurecida por el mito de origen de la disciplina en forma de un canon de "teoría clásica" relacionada con la modernidad europea. La sociología estuvo involucrada en el mundo del imperio desde el principio. Hacer que el canon sea más inclusivo, en términos de género, raza e incluso a nivel mundial, no es una corrección adecuada. Los tipos importantes de conocimiento social, incluidos los conocimientos basados en el movimiento y los indígenas, se resisten a la canonización. El giro hacia las perspectivas decolonial y meridional, que ahora está ocurriendo en las ciencias sociales, abre nuevas puertas en la historia del conocimiento. Estas pueden vincularse con una visión más sofisticada de la producción colectiva de conocimiento por parte de las fuerzas de trabajo que están interactuando cada vez más, aunque de manera desigual. Surgen potenciales para una sociología más comprometida.

PALABRAS CLAVE: Historia de la sociología; Formación canónica; Teoria clásica; Colonialismo; Sur global. 


\section{INTRODUCTION: RHODES MUST GO}

$\mathrm{O}$ n the University of Cape Town's upper campus, the main buildings stretch in rows across a hill face on the lower slopes of the Table Mountain complex. The mountain is the iconic backdrop to the city first called Kaapstad, and the upper campus buildings have a magnificent north and east view across the Cape Flats towards the rest of Africa. The site was donated by Cecil Rhodes, the mining magnate who, in the late nineteenth century, was the most renowned and ruthless promoter of British imperial expansion in Africa. He had become Prime Minister of Cape Colony, where he was responsible for coercive laws intended to force much of the indigenous population off the land, and thus create a cheap labour force for white farmers, mining companies and other businesses. In the 1930s, the University put up a bronze statue of Rhodes at the edge of its main plaza.

In 2015, a campaign led by a group of Black students pressed the University to remove the statue. Quickly becoming known as the "Rhodes Must Go" movement, the students portrayed the statue as a symbol of continuing White domination of the University, and the failure of the social "transformation" promised after Apartheid. The argument broadened to racial inequality in the staffing and student intake of the University, and demands for Africanization of the curriculum, the movement locating itself in an anti-colonial Black activist tradition, invoking Frantz Fanon and Steve Biko.

Among the complexities of the situation were the fact that the University of Cape Town had been a centre of White opposition to the Apartheid regime; that the country had been governed since 1994 by an African National Congress leadership that had taken the whole economy in a neoliberal direction, with widespread unemployment among the Black working class, but growing privilege for a Black minority; that in the neoliberal knowledge economy, the University of Cape Town was South Africa's leading institution in the world rankings (indeed, Africa's leading institution); that the University's curriculum was mainly derived from European and North American knowledge systems, though some of its staff have been working with alternative knowledges; and that the ANC government was under challenge from Black nationalist politicians, whose rhetoric overlapped with that of the Rhodes Must Go movement.

The University authorities soon agreed to remove the statue, and Rhodes has gone. But the debates and tensions triggered by the campaign remain, and they are important far beyond Cape Town. They raise questions about the imperialist history of the knowledge system on which universities all over the world depend - the "official knowledge", as the North American educationist Michael Apple (1993) has termed it, that is still embedded in 
curricula, assessment practices, and the professional cultures of researchers and teachers. The homogeneity of this official knowledge is an absolute presupposition of the global rankings of universities that are now so important to policymakers and university managers.

In this essay, I will explore the postcolonial politics of official knowledge in the discipline of sociology, and particularly contestations around the canon of "classical" texts and authors in this discipline. My material comes mainly from Anglophone sociology. I'm aware that regional trajectories in intellectual life differ. The course of events in the discipline is not the same in post-communist countries as in countries with a continuous history of capitalism (Titarenko, 2012); nor is it the same in German-speaking countries as in English-speaking countries, even in the same region. But I think the issues raised are widely relevant.

\section{THE FOUNDING FATHERS: CANON AS PSEUDO-HISTORY}

n Anglophone countries, the history of sociology is usually taught to students along the
following lines. In the eighteenth and nineteenth centuries, society in Europe and North America went through a deep transformation, involving the industrial revolution, the advent of democracy, the rise of bureaucracy and the modern state, and cultural changes of which the core was secularization. A small group of brilliant intellectuals interpreted this change and developed a science of modern, as distinct from traditional, society. This was called sociology. The key figures in developing this science were: Karl Marx, Émile Durkheim and Max Weber. Their major texts, notably Capital, Suicide, The Division of Labour in Society, and Economy and Society, form a canon widely known as Classical Theory. A less distinguished second team also contributed, made up of Tönnies, Spencer, Sumner, Simmel and Pareto.

This is a crude account of the story, but, in truth, the textbook version of "that brilliant age in which the foundations of the discipline were laid" (Bottomore and Nisbet, 1978: $x$ ) is often as crude as this. And the idea of a founding trio as the core authors of Classical Theory has been backed by scholarship that is far from crude, but is insistent. Jeffrey Alexander's monumental Theoretical Logic in Sociology $(1982,1983)$ after disposing of positivism, presented an account of classical theory in the form of an intricate analysis of: Marx, Durkheim, and Weber. Anthony Giddens' influential Capitalism and Modern Social Theory (1971) analyzed the writings of: Marx, Durkheim and Weber. Peter Baehr (2002) more recently elaborated a defence of the idea of classics for sociology, endorsing the conventional list, though he does not like them to be called a "canon".

This picture of sociology spread around the world. A generation ago, Cora Baldock and Jim Lally (1974: chapter 8) conducted a little survey of the theoretical perspectives adopted 
by Australians and New Zealanders in the then-new academic discipline of sociology. Three schools were named in the responses: Marxist, Weberian and Durkheimian. I do not want to embarrass colleagues by naming bad examples, but I can assure the reader that more than thirty years after that, an Australian introductory textbook could still introduce the subject with a story of "The emergence of sociology as a discipline" entirely consisting of: 6 pages on Durkheim; 10 pages on Marx; and 6 pages on Weber.

Twenty years ago, I wrote a long essay, Why is Classical Theory Classical? (Connell, 1997), that raised severe doubts about the conventional story. I pointed to the work of historians who had shown that the huge fame of Durkheim and Weber, and even the inclusion of Marx as a sociologist, were late developments in the history of the discipline (Platt, 1995). Substantially, the canonization of this trio occurred from the 1930s to the 1960s, mainly in the United States. It was not a story that originated in the founding generations themselves. The sociologists of that period regarded sociology as the creation of a much wider group of pioneers, and would name two or three dozen of them in the Introductions to their treatises. Lester Ward, for instance, in the 1897 edition of his Dynamic Sociology, listed 37 notable contributors to the new science. His list included Durkheim and Tönnies, but neither Marx nor Weber.

The language of "social science", devised by Comte in the first half of the century, was taken up around the time of his death in the 1850s by a broad spectrum of reformers. $A$ generation later, their writing and activism was unevenly converted into an academic discipline that enthusiastically claimed to be a full-blown empirical science. The claim to be a science meant speculative generalizations supported by a large body of information. Therefore, the recording and classification of social knowledge became a major part of the enterprise. Works such as Spencer's immensely influential Principles of Sociology, published in the 1870s, or Sumner's Folkways a generation later, took the form of huge accumulations of descriptions of social institutions, customs and events.

Investigations of social conditions in the metropole certainly went into this brew, but the gaze of Spencer, Ward, Engels, Letourneau, Tönnies, Durkheim, Sumner, Giddings, Hobhouse and their colleagues ranged far beyond Europe. They gathered and incorporated vast amounts of data from the colonized world, and from earlier periods of history. Sociology, to this generation, was not only about industrializing Europe and North America, indeed it was not primarily about modernity.

Rather, the conceptual framework of sociology was based above all on the contrast between metropole and colony. The distinction of "primitive" from "advanced" social forms underpinned the concept of social progress that governed the new science for its first two 
generations. And this was a distinction that was founded on the assumption of inherent difference between colonized and colonizer. Its cultural roots go back as far as the contrast of Christian and pagan in mediaeval European culture that legitimated the crusades in Palestine and Prussia, and the fierce disputes that arose in Spain in the sixteenth century about the legitimacy of overseas conquest.

It is not accidental that sociology as an organized knowledge project emerged at the high tide of European imperialism, both overseas and overland. The doctrine of progress gave the liberal intellectuals who created the discipline a solution to the severe cultural dilemma they faced as beneficiaries of imperialism. By the 1890s, it was globally-sourced data, rather than local empirical investigation, that legitimated "sociology" as a science. It is highly illuminating to read the major attempt in the "classical" period to survey all sociological knowledge, L'année sociologique, the periodical put out by Durkheim's group. It abstracted reports from all over the colonized world, and texts about other periods of history, in greater number than texts about modern Europe. Themes of industrialization, class struggle, or bureaucracy were very far from being dominant concerns.

In substance and in framing, sociology was global from the start. Though my sketch is being replaced by more comprehensive narratives, the intimate relationship between sociology and empire is abundantly proven by more recent historical research (Steinmetz, 2013). This connection was the fundamental fact suppressed by the internalist narrative of the origins of sociology and the selection of Marx, Weber and Durkheim rather than, say, Spencer, Letourneau and Sumner. The creation of a canon followed a turn towards the empirical study of the metropole itself, after the crisis of Comtean sociology in the early twentieth century. Sociology as a world-viewing intellectual project among the liberal bourgeoisie in Europe collapsed in the face of war, working-class struggle, nationalism and authoritarian rule.

Sociology faced something of a legitimation crisis as it sought a home in the academic ecology of US universities after the Great War. Re-interpreting it as a science of modernity, and emphasising its roots in Great Books of the Western World, helped to handle this problem. In truth, the Great Books had hardly any relation to the techniques of the Chicago School fieldworkers and the Columbia School quantifiers, which, since the 1920s, were producing the bulk of North American sociology. But the disconnection was mostly ignored - "theory" and "method" were taught in separate courses. Ironically, it was a conservative version of metropole-centred sociology that was exported to developing countries during the Cold War, when creating social sciences on the American model in the global South became a project for the US corporate foundations, the US universities and the American state. 
The creation of a canon was not just the formulation of an idea. It became a material practice, in the form of a pedagogy that made the study of "the classics" a required part of the professional formation of an academic sociologist. A course on "Classical Theory" became a standard element in the sociology PhD programmes of US universities (It was my embarrassment at having to teach such a course that led to writing Why is Classical Theory Classical?).

The pedagogy in that pre-Internet era required written material to work with, so the major texts of chosen Fathers were excerpted, republished, and translated into English if they had not previously been; a typical example is Wolff's (1959) English-language version of Simmel. An industry of exposition, celebration, biography, commentary and criticism arose, including Alexander's and Giddens's books. The collectively sustained fiction of the Founding Fathers could then be proudly presented to undergraduates, at the start of their studies (literally in Chapter 1 of many Sociology 101 textbooks), as the truth about the origins of their discipline.

In Alan Swingewood's A Short History of Sociological Thought (2000: x) "Marx, Weber and Durkheim have remained at the core of modern sociology", not just because they began it, but because of their depth, rigour and ability to raise disturbing questions about modern society. This was widely agreed. Alexander's 1987 paper "The centrality of the classics" (1987) can stand for many. As well as being texts of unexampled brilliance, the classics serve a functional purpose for sociology. They allow - indeed invite - argument within a shared space; the centrality of the classics makes interpretation a key form of theoretical argument, as the classical texts become a battleground. That was a relatively economical argument. Arthur Stinchcombe's plaintive essay "Should sociologists forget their mothers and fathers?" (1982) claimed that the classics served no less than six functions for sociology.

In Alexander's version, strikingly, the defence of sociology's foundation myth returns to the terrain of religion, where the interpretation of a set of honoured texts - hermeneutics, ijtihad - is a major form of scholarship and devotion. Yet the history of religion might remind us that not only what the canon means, but what the canon itself is, can be a subject of fierce dispute. There have been debates about which of the Gospels are to be accepted as valid; whether the Apocrypha should form part of the Bible; and which of the hadiths are legitimately taken as words of the Prophet Mohammed, peace be upon him.

In literature, the other great source of the contemporary idea of a canon, the sense in which a set of classics is necessarily a back-formation, not a history, is even clearer. Attempts at defining, purging, expanding and exploding the canon of English literature have been central activities in Anglophone literary criticism for a long time (Showalter, 1977). 


\section{UNSETTLING THE CANON}

T $\mathrm{t}$ is consistent with this broader history that the canon of classical sociology has been subject to amendment. The Sociology 101 textbooks of the 1970s were usually satisfied with Marx, Durkheim and Weber. That choice came under fire from feminist sociologists, who became a large constituency in US sociology during the 1970s and 1980s, and who observed that even the second team was entirely composed of blokes. African-American sociologists at the same time observed that the canonical list was entirely White. We could also observe that it was entirely bourgeois, though the inclusion of Marx gave symbolic protection from socialist critique; during the student movement of the 1960s and 1970s, sociology even became the main academic vehicle for new-left radicalism.

Textbook writers and their publishers were sensitive to these changes in the market, so Sociology 101 textbooks in time amended the membership list. It is now common to see a nice picture of Jane Addams included in the chapter about classical sociology; alternatively, a picture of Harriet Martineau, heralded as the first sociologist woman (a concept that would have surprised her). Neither Addams's nor Martineau's writings seem to have been canonized, however. That did happen for the amendment made in response to African-American criticism. W. E. B. Du Bois had certainly produced notable sociological books, and The Philadelphia Negro and The Souls of Black Folk have now been reprinted and anthologised.

This has not happened, however, for Du Bois's later writings. He did not stop writing social analysis when he became deeply involved with the anti-colonial movement in Africa, with peace campaigns, and eventually with the international communist movement. That seems to me an important limit to his canonization. It highlights the way in which the textbook version of the foundation story has remained focussed on the global North.

A more radical revision is suggested by nominating thinkers from outside the North Atlantic world as founders. The most favoured is the eighth century (AH)/fourteenth-century (CE) Maghrebian politician and intellectual Ibn Khaldun, nominated by Fuad Baali (1988) not as a founder of sociology but as the founder of sociology. Ibn Khaldun's Muqaddimah is indeed a remarkable text, that canvasses issues of rural/urban social difference, state formation, and the socio-cultural roots of political instability and change. Ibn Khaldun's historical writing, to which the Muqaddimah is a conceptual introduction, is, Yves Lacoste (1980) observed, a late flowering of a broad historiographical tradition in Muslim culture. Ibn Khaldun turned this tradition towards social analysis, partly in response to the political problems of his own society, partly in a critique of over-rationalist strains in Islamic philosophy. 
Syed Farid Alatas $(2006,2010)$ has emphasised the creative potential of this turn. Crucially, Alatas has shown how the Muqaddimah can provide a framework for understanding political and religious change in other times and places, and has offered concrete examples. Alatas has thus moved beyond the purely programmatic to the actual construction of sociological analyses on non-Eurocentric foundations, with Ibn Khaldun's work playing the backgroundconceptual-framing role, which, in the Eurocentric picture of sociology, is played by the texts of Marx, Weber and Durkheim.

Can this process be extended? Indeed, should it be? Do we want to reconstitute the canon of classical sociology on a world, rather than a North-Atlantic, basis?

Some commentary on my book Southern Theory (Connell 2007) has seen it as an attempt to do just that. I can understand how the book might be read that way, given the familiarity of canonical thinking in sociology, and the fact that the book begins with a critique of the European canon. And I don't mind urging that some of the texts discussed in that book should be read by any people who might think of themselves as sociologists. Solomon Tshekisho Plaatje's Native Life in South Africa, published four years after Durkheim's Elementary Forms of Religious Life and six years before Weber's Economy and Society - and a better guide than either of those to the realities of the early twentieth century - would be one.

Nevertheless my intention was not to identify a few decisive figures on whom traditions could be built. It was to show the tremendous wealth of social analyses that were generated by social change and social struggle in the colonial and postcolonial world, and the diverse genres in which those ideas were expressed. The sources range from political pamphlets through religious sermons to economic policy statements to ethnographies.

Southern Theory does nominate names, and discuss specific texts, in an attempt to show all this concretely, to provide proof of the main claim. However, the text, unlike most books with "theory" in their title, is not an attempt at a history or a formal treatise. It is, rather, a narrative of the way in which one intellectual from a settler colony, carefully trained in Eurocentric social science, encountered people, texts, stories and problems from beyond the boundaries of that training.

Prophetically, one of the first postcolonial texts I ever read was C. L. R. James Beyond a Boundary (1963), the best book written about cricket and possibly the best ever written about sport. Much later I read James's devastating history The Black Jacobins, which, in 1938, said most of what ever needed to be said about the Enlightenment. The implication of this approach was that, rather than being only a narrow group of classic-standard theorists, there were many more out there of comparable insight and value. And it is not hard to nominate 
more. Southern Theory doesn't discuss James himself, nor his even more famous Caribbean contemporary Frantz Fanon. Nor does it discuss the social thought of Anouar Abdel-Malek, Bina Agarwal, Samir Amin, He-Yin Zhen, Kartini, José Carlos Mariátegui, Kwame Nkrumah, José Rizal (who is discussed by Alatas), Heleieth Saffioti, Sun Yatsen, or Leopoldo Zea, who are, by no means, a second team. And we could go on - as I have done in Connell (2015a), on gender theorists.

The recent discussion of global plurality in sociology, sponsored by the International Sociological Association, has frequently taken the form of national narratives - see the valuable collections edited by Patel (2010) and by Burawoy, Chang and Hsieh (2010). It is a genre to which I have contributed, describing the formation of sociology in Australia (Connell, 2015b), so I don't consider it a bad approach. It provides extremely useful documentation, among other things demonstrating the different sequences of intellectual history in different world contexts. A local history can open up new themes that are little treated in Northern theory. An example is the powerful awareness of space in the social imagination of the global periphery, documented in João Maia's $(2008,2011)$ research on the history of Brazilian social thought.

But there are limits to a national or even regional narrative, when many social and intellectual developments in the world of imperialism and post-imperial globalization operate on a much larger scale. There is a risk that the demonstration of plurality will fall back into the dubious project, all too familiar in the global North as well as in the South, of trying to define a unique national or regional style, ethos, spirit or philosophy (For an example from the global North, see Levine (1995); for a shattering critique of this kind of project, see Hountondji (1976)).

At the end of the day, re-working the canon, even de-colonizing the canon, and substituting a more diverse group of classics, is not a methodologically adequate way of relating to the history of social thought. When researching the disciplinary history of sociology, we certainly need to study why a narrow canon and an unbelievable foundation story were invented and institutionalized. But we should not make the same mistake again.

\section{HISTORIES DIFFICULT TO CANONIZE}

here are important forms of social thought that resist being formulated in canonical terms.
A good deal of social analysis comes from radical social movements - labour movements, feminism, gay liberation, landless people's movements, movements of subordinated castes or ethnic groups, nationalist movements, anticolonial movements. Some of these movements 
have given rise to important texts, such as B. R. Ambedkar's 1936 Annihilation of Caste - a powerful statement on the contradictions of Hindu society from the viewpoint of the oppressed castes, including a sharp critique of Gandhi. But such statements have force mainly because of the collective knowledge production behind them.

In recent years, the social sciences have been coming to terms with the fact that knowledge formation and circulation is global, and is structured both by the history of imperialism and the tremendous inequalities, as well as the technical possibilities, of the neoliberal world economy today. Postcolonial, decolonial and Southern perspectives have been elaborated in fields as diverse as education (Epstein and Morrell, 2012), history (Chakrabarty, 2000), disability studies (Meekosha, 2011) and criminology (Aas, 2012), as well as sociology in general (Sitas, 2006; Rodríguez, Boatcă and Costa, 2010; Reuter and Villa, 2010) and specific fields such as industrial sociology (Keim, 2008).

The tendency of this literature as a whole, I would argue, is anti-canonical. It not only demonstrates the inadequacy of a European/North American canon, but also reveals obstacles to the crystallization of any alternative canon derived from the Third World, the Global South, or the postcolonial world. For instance, Maria Lucia Maciel and Sarita Albagli (2009), exploring how the idea of "knowledge societies" appears from the global South, show how generalized knowledges fail in practice to circulate freely, while local linkages and tacit knowledge matter a great deal.

Following another line of thought, Marina Blagojevi ć (2009) observes how knowledge formation in the Eastern European semi-periphery has been shaped by the de-development of the region after the collapse of communism and the arrival of neoliberalism, creating new conditions for knowledge workers. These conditions include privilege and funding for knowledge workers who can attach themselves to institutions and agendas of the metropole.In the postcolonial debates about knowledge, the concept of "indigenous knowledge" has played a leading role. It is often the second term in a contrast with "Western science" or a Western knowledge system, as in Catherine Odora Hopper's valuable collection of African research and theory, Indigenous Knowledge and the Integration of Knowledge Systems (2002). Indigenous epistemology is the vital point of alterity and resistance in the "decolonial" agenda articulated in Walter Mignolo's discussions of Latin America (2005, 2007). Indigenous language, culture and experience in Aotearoa New Zealand are the bases of Linda Tuhiwai Smith's influential critique of mainstream social science in Decolonizing Methodologies (2012).

This is a highly disputed arena; it is not easy to define what indigenous knowledge is. There has been, for instance, a long and bitter debate about the concept of an "African philosophy" that is supposedly embedded in the oral cultures of colonized African societies (Serequeberhan, 
1991; Hountondji, 2002). The idea of indigenous knowledge does get mixed up with nationalist agendas and very dubious politics. For instance, the decision by the Mbeki government in South Africa, which had launched an inspiring "African renaissance" agenda, to reject prevailing interpretations of the HIV epidemic as being racist, and to define indigenous healing knowledge as an adequate response to AIDS, led to a public health disaster (Cullinan and Thom, 2009).

Yet there can be no question that colonized peoples in all parts of the world did have extensive knowledge of their worlds, and practices and technologies based on this knowledge. Paulin Hountondji and his colleagues documented this for West African societies in the very important book Endogenous Knowledge: Research Trails (1997), which ranges across the iron industry, rainmaking, number systems, prediction, zoological nomenclature, pharmacology, mental disorder and more.

Even those societies which European colonizers and sociologists regarded as the most primitive of the primitive - the San and Khoikhoi in southern Africa, the Fuegian communities in the far south of America, and the Aborigines of Australia (whose religion Durkheim insisted was the most elementary form, despite the fact that he never set foot in Australia) - all had environmental, biological and social expert knowledge and sustainable technologies, not to mention complex religious cultures.

As Crossman and Devisch (2002) observe, discussions of indigenous knowledge have focussed on two fields, agriculture and indigenous medicines; these are the topics of most interest to transnational corporations and development agencies. I would emphasise, however, that indigenous knowledge, which is far from static, also includes a large component of social knowledge. Here are records of social processes, concepts for social relations, ways of understanding social conflicts and techniques for resolving them, ideas about education. And of course, knowledge of the social effects of colonization - for a striking example, read Somerville and Perkins' beautiful book Singing the Coast (2010).

This knowledge may make connections that are rare in Eurocentric sociology. The representation of social relations in Australian central-desert Aboriginal art, for instance, persistently connects people with the land, with particular places and specific routes across the country. The land is an absolutely central issue in the contemporary, as well as pre-colonial, culture and politics of Aboriginal communities (Yunupingu, 1997).

Indigenous knowledge resists being formulated in terms of a canon. Where it exists in oral form, it may be captured in a written record, as Akinsola Akiwowo (1986) did in the most-discussed case of using oral tradition (in this case, priestly poems in Yoruba language) as the basis for writing a formal sociology. But oral traditions exist in many variants, and are constantly re-composed in performance, so it is difficult to claim authority for any transcription. 
As Jimí Adésinà (2002) observes in a reflection on Akiwowo's project, by abstracting from the situation, it is easy to miss their purposive character, the political agenda they carry and the power relations they may embody.

This point is even more powerful when the story, the ritual or the artwork is strongly linked to specific places. This is an experience I have had, at Ubirr in Kakadu (northern Australia). Hearing a traditional story told in the place to which it refers, experiencing the spirit beings moving and the events unfolding around me on the site, makes entirely real the interpenetration of the Dreaming and the present, so alien to mainstream Europeanderived social science, but so central to indigenous knowledges in Australia. However, outside that place, how can we generalize the knowledge contained in that story? Only by a radical abstraction from the land - an operation all too similar to that destruction of Aboriginal links to the land that was the core of colonization.

\section{TOWARDS A MORE RADICAL VIEW OF INTELLECTUAL LABOUR}

illie Thayer (2010) has recently pointed to the importance of a vast and heterogeneous
"counterpublic" in which feminist thought about gender inequality circulates internationally. It is characteristic of radical movements to be suspicious of hierarchies, not only in the wider society, but within movements themselves. The Women's Liberation movement, to take one example, put much energy into decentralizing decision-making and collectivizing representation. The tendency towards shared knowledge production is, according to a thesis developed by the Arena group in Australia, a characteristic of intellectual workers in advanced capitalism (Sharp, 1968; Sharp and White, 1968; Connell, 2016). In a society increasingly dependent on organized knowledge, intellectual labour is increasingly collectivized. The conditions of this labour emphasise lateral, not hierarchical, relations among intellectual workers and thus promote a democratic consciousness.

A notable example is the work of the "dependency" school of thought in Latin America. In the English-speaking world, this work has been mainly known through the writings of Andre Gunder Frank (1967). As Fernanda Beigel's (2010) admirable study of dependency theory makes clear, the ideas were very much a collective product. Building on the pioneering work in development economics of Raúl Prebisch and Celso Furtado, a group of younger scholars centred in Santiago de Chile in the 1960s and early 1970s generated a multifaceted critique of mainstream European/US-derived economics, of orthodox Marxism, and of the initial CEPAL model of import replacement industrialization. It was the interactions across a number of research groups spread through several institutions, rather than the centrality of any classics, that enabled this remarkable surge of creativity. 
Yet there are tendencies that work in favour of canons. Making a canon is an exercise in creating celebrity, and both popular mass media and academic life show the power of celebrity mechanisms (Krieken, 2012). Once a degree of celebrity is established, it can become selfreinforcing, accumulating more and more "mentions" (as Twitter puts it) simply because the person or text is already well-known.

I have had a minor experience of celebrity in one field of social science, as my work is well known in the sub-field of gender research concerned with the study of masculinities. It has become clear, looking at the way this work has been taken up, that being academically "celebrated" is not equivalent to being well understood. A sharp narrowing of meaning, soon amounting to distortion, accompanied the growth of recognition (Connell and Messerschmidt, 2005).

I know that my work in this field has also assisted some really excellent research and theorization by others. So the cumulative and self-corrective growth of knowledge does happen in this field, as it should. But it is not the celebrity or canonical status of a text like Masculinities (Connell, 2005) that produces this effect. It is the hard work and independent thinking of the next wave of scholars and activists that does. The main effect of the celebrity is a spurious authorization of over-simplified and mostly backward-looking accounts of the subject.

Thus, I have a reason to be sceptical of the claim that the "centrality of the classics" is good for sociology. The mechanisms and consequences of celebrity certainly produced truncated and distorted accounts of the work of Marx, Durkheim and Weber. The extraordinary interpretation of Marx as a "conflict theorist" was one of them. Another was the way Anglophone sociology's Durkheim almost completely missed the real Durkheim's urgent commitment to build secular republican culture in the France of the Dreyfus affair.Yet a third misreading concerned Weber.

To a reader used to the bland Anglophone Weber as Founding Father, or the abstracted intellect discussed by Alexander and Giddens, it was a revelation to discover Dr Max as an ambitious, but vulnerable player in the tough world of National-Liberal politics, economic policy struggles, imperial rule and militarism. As Keith Tribe (1989:12) drily remarked, "what Weber has come to mean in the sociological tradition is often of dubious value".

It is not only that canonization leads to boring misinterpretations of the life and work of intellectuals who are, in their own right, exciting and certainly worth reading. The process also has serious consequences for the discipline in which it happens. It implies that the creation of sociological perspectives was a matter of isolated genius. The point that Beigel makes about the creation of the dependentista framework also applies to the creation of sociology itself as an academic field in the metropole, from the 1880s to the 1900s. This involved the collective labour of a whole network of intellectuals, in five or six countries, creating departments, 
journals, conferences, associations, curricula and textbooks. As noted earlier, sociologists at the time took a collective, not canonical, view of the making of their discipline.

Most problematically, the reliance on a canon to provide structure, identity or boundaries to a field of knowledge - the claim most persistently made for the canon in sociology obstructs thinking. It obstructs the capacity to think for oneself, it obstructs willingness to leap beyond those boundaries and put that professional identity at risk. It is really bizarre that the polemic of an embattled metropolitan intellectual in the 1890s about the methodological separateness of the social should be taught to students in India or China in the 2010s as part of the definition of their field of study, at a time when they are choking in the pollution of their cities and scared by anthropogenic climate change.

In the wake of the inconclusive discussion of Michael Burawoy's agenda for "public sociology" (Clawson et al., 2007), some colleagues have become severely despondent about the lack of impact that sociology is having in current public affairs, while neoliberal politics gets a harder grip and global antagonisms deepen (Prosono, 2012). One of the reasons for ineffectuality is surely the structure of official knowledge in sociology itself.

The decolonial and Southern perspectives discussed above imply that any serious contemporary re-thinking of the social sciences must work on a world scale. This requires us to understand the workforce of knowledge creation on a world scale, with attention to the neo-colonial situations in which large parts of that workforce operate (Mkandawire, 2005). The material inequalities among knowledge workers on a world scale are among the severe problems of contemporary social science.

However, a global perspective also opens up great possibilities for intellectual renovation. Rhodes Must Go, and we are not short of ideas for what should replace colonial structures of knowledge: including the epistemological pluralism identified by many thinkers (Olivé et al., 2009), the "theory from the south" suggested by Jean and John Comaroff (2012), the "connected sociologies" proposed by Gurminder Bhambra (2014), and the all-important detailed work of networks of researchers in global-South contexts, like the South African education research introduced by Epstein and Morrell (2012).

Sociology does have a capacity to speak to the critical issues of contemporary society. But it will do so only if more sociologists are willing to think for themselves, form new kinds of international connections, and take intellectual and personal risks. In short, do as Marx, Durkheim and Weber did, rather than endlessly repeat what they said. It won't get you into the American Sociological Review. But it might help change the world. 


\section{REFERENCES}

AAS, Katja Franko. The Earth is one but the world is not: criminological theory and its geopolitical divisions. Theoretical Criminology, v. 16, n. 1, 2012, p. 5-20.

ADÉSINÀ, Jìmí O. Sociology and Yorùbá studies: epistemic intervention or doing sociology in the "vernacular"? African Sociological Review, v. 6, n. 1, 2002.

AKIWOWO, Akinsola A. Contributions to the sociology of knowledge from an African oral poetry. International Sociology, v. 1, n. 4, 1986, p. 343-358.

ALATAS, Syed Farid. Alternative Discourses in Asian Social Science: Responses to Eurocentrism. New Delhi: Sage, 2006.

Religion and reform: two exemplars for autonomous sociology in the non-Western context. In: PATEL, Sujata (ed.). The ISA Handbook of Diverse Sociological Traditions. Los Angeles: Sage, 2010, p. 29-39.

ALEXANDER, Jeffrey C. The centrality of the classics. In: GIDDENS, Anthony; TURNER, Jonathan H. (ed.). Social Theory Today. Cambridge: Polity Press, 1987, p. 11-57.

ALEXANDER, Jeffrey C. Theoretical Logic in Sociology. V. 2. The Antinomies of Classical Thought: Marx and Durkheim. Berkeley: University of California Press, 1982.

ALEXANDER, Jeffrey C. Theoretical Logic in Sociology. V. 3. The Classical Attempt at Theoretical Synthesis: Max Weber. Berkeley: University of California Press, 1983.

AMBEDKAR, Bhimrao Ramji. Annihilation of Caste: Speech Prepared for the Annual Conference of the Jat-PatTodak Mandal of Lahore But Not Delivered. London: Verso, 2014 [1936].

APPLE, Michael. Official Knowledge: Democratic Education in a Conservative Age. New York: Routledge, 1993.

BAALI, Fuad. Society, State, and Urbanism: Ibn Khaldun's Sociological Thought. Albany: State University of New York Press, 1988.

BAEHR, Peter. Founders, Classics, Canons: Modern Disputes over the Origins and Appraisal of Sociology's Heritage. New Brunswick/London: Transaction Publishers, 2002.

BALDOCK, Cora V; LALLY, Jim. Sociology in Australia and New Zealand: Theory and Methods. Westport: Greenwood Press, 1974.

BEIGEL, Fernanda. Dependency analysis: the creation of new social theory in Latin America. In: PATEL, Sujata (ed.). The ISA Handbook of Diverse Sociological Traditions. Los Angeles: Sage, 2010, p. 189-200.

BHAMBRA, Gurminder K. Connected Sociologies. London: Bloomsbury Academic, 2014.

BLAGOJEVIĆ, Marina. Knowledge Production at the Semiperiphery: A Gender Perspective. Belgrade: IKSI, 2009.

BOTTOMORE, Tom; NISBET, Robert (eds). A History of Sociological Analysis. London: Heinemann, 1978.

BURAWOY, Michael; CHANG, Mau-kuei; HSIEH, Michelle Fei-yu (eds). Facing an Unequal World. Taipei: Academia Sinica, 2010.

CHAKRABARTY, Dipesh. Provincializing Europe: Postcolonial Thought and Historical Difference. Princeton: Princeton University Press, 2000. 
CLAWSON, Dan et al. (eds). Public Sociology. Fifteen Eminent Sociologists Debate Politics and the Profession in the Twenty-first Century. Berkeley: University of California Press, 2007.

COMAROFF, Jean; COMAROFF, John L. Theory from the South: or, How Euro-America is Evolving Toward Africa. Boulder/London: Paradigm Publishers, 2012.

CONNELL, Raewyn. 2016. Theorizing intellectuals. Arena Journal, no. 45/46, Special Issue "Cold War to Hot Planet: Fifty Years of Arena", 12-27.CONNELL, Raewyn. Masculinities. 2nd edition. Cambridge: Polity Press, 2005.

Meeting at the edge of fear: theory on a world scale. Feminist Theory, v. 16, n. 1, p. 49-66, 2015 a.

. Setting sail: the making of sociology in Australia, 1955-75. Journal of Sociology, v. 51, n. 2, 2015b, p. 354-369.

CONNELL, Raewyn. Southern Theory: The Global Dynamics of Knowledge in Social Science. Cambridge: Polity Press, 2007.

CONNELL, Raewyn. Why is classical theory classical? American Journal of Sociology, v. 102, n. 6, 1997, p. 1511-57.

; MESSERSCHMIDT, James W. Hegemonic masculinity: rethinking the concept. Gender and Society, v. 19, n. 6,2005, p. 829-859.

CROSSMAN, Peter; DEVISCH, René. Endogenous knowledge in anthropological perspective: a plea for a conceptual shift. In: HOPPERS, Catherine A. Odora (ed.). Indigenous Knowledge and the Integration of Knowledge Systems. Claremont: New Africa Books, 2002, p. 96-125.

CULLINAN, Kerry; THOM, Anso. The Virus, Vitamins and Vegetables: The South African HIVIAIDS Mystery. Cape Town: Jacana, 2009.

EPSTEIN, Debbie; MORRELL, Robert. Approaching Southern theory: explorations of gender in South African education. Gender and Education, v.24, n. 5, 2012, p. 469-482.

FRANK, Andre Gunder. Capitalism and Underdevelopment in Latin America: Historical Studies of Chile and Brazil. Harmondsworth: Penguin, 1971 [1967].GIDDENS, Anthony. Capitalism and Modern Social Theory: An Analysis of the Writings of Marx, Durkheim and Max Weber. Cambridge: Cambridge University Press, 1971.

HOPPERS, Catherine A. Odora (ed.). Indigenous Knowledge and the Integration of Knowledge Systems. Claremont: New Africa Books, 2002.

HOUNTONDJI, Paulin J. African Philosophy: Myth and Reality. 2 ed. Bloomington: Indiana University Press, 1996 [1976].

HOUNTONDJI, Paulin J. (ed). Endogenous Knowledge: Research Trails. Dakar: Codesria, 1997.

The Struggle for Meaning: Reflections on Philosophy, Culture, and Democracy in Africa. Atenas: Ohio University Press, 2002.

JAMES, Cyril Lionel Robert. Beyond A Boundary. Durham: Duke University Press, 1993 [1963].

The Black Jacobins: Toussaint L'Ouverture and the San Domingo Revolution. New York: Vintage Books, 1963 [1938]. 
KEIM, Wiebke. Vermessene Disziplin: Zum konterhegemonialen Potential afrikanischer und lateinamerikanischer Soziologien. Bielefeld: Verlag, 2008.

KRIEKEN, Robert van. Celebrity Society. London/New York: Routledge, 2012.

LACOSTE, Yves. Ibn Khaldun: The Birth of History and the Past of the Third World. London: Verso, 1984.

LEVINE, Donald N. Visions of the Sociological Tradition. Chicago: University of Chicago Press, 1995.

MACIEL, Maria Lucia; ALBAGLI, Sarita. Knowledge societies, seen from the South: local learning and innovation challenges. International Social Science Journal, n. 195, 2009.

MAIA, João Marcelo Ehlert. A terra como invenção: o espaço no pensamento social brasileiro. Rio de Janeiro: Zahar, 2008.

Space, social theory and peripheral imagination: Brazilian intellectual history and de-colonial debates. International Sociology, v. 26, n. 3, 2011, p. 392-407.MEEKOSHA, Helen. Decolonising disability: thinking and acting globally. Disability \& Society, v. 26, n. 6, 2011, p. 667-682.

MIGNOLO, Walter D. Delinking: The rhetoric of modernity, the logic of coloniality and the grammar of decoloniality. Cultural Studies, v. 21, n. 2-3, 2007, p. 449-514.

The Idea of Latin America. Oxford: Blackwell, 2005.

MKANDAWIRE, Thandika (ed.) African Intellectuals: Rethinking Politics, Language, Gender and Development. Dakar: Codesria/ London: Zed Books, 2005.

OLIVÉ, León et al. Pluralismo epistemológico. La Paz: Muela del Diablo/Comuna/Clacso/Cides-Umsa, 2009.

PATEL, Sujata (ed.). The ISA Handbook of Diverse Sociological Traditions. Los Angeles: Sage, 2010.

PLATT, Jennifer. The United States reception of Durkheim's The Rules of Sociological Method. Sociological Perspectives, v. 38, n. 1, 1995, p. 77-105.

PROSONO, Marvin. Bystander sociology and the Sonderbehandlung of the social. In: KALEKIN-FISHMAN, Devorah; DENNIS, Ann (ed.). The Shape of Sociology for the $21^{\text {st }}$ Century. Tradition and Renewal. Los Angeles: Sage, 2012, p. 267-280.

REUTER, Julia; VILLA, Paula-Irene (ed.). Postkoloniale Soziologie: Empirische Befunde, theoretische Anschlüsse, politische Intervention. Bielefeld: Transcript, 2010.

RODRÍGUEZ, Encarnación Gutiérrez; BOATC区, Manuela; COSTA, Sérgio (ed.). Decolonizing European Sociology: Transdisciplinary Approaches. Farnham/Surrey/Burlington: Ashgate, 2010.

SEREQUEBERHAN, Tsenay. African Philosophy: The Essential Readings. New York: Paragon House, 1991.

SHARP, Geoff. A revolutionary culture. Arena, n. 16, 1968, p. 2-11.

; WHITE, Doug. Features of the intellectually trained. Arena, n. 15, 1968, p. 30-33.

SHOWALTER, Elaine. A Literature of Their Own: British Women Novelists from Brontë to Lessing. Princeton: Princeton University Press, 1977.SITAS, Ari. The African Renaissance challenge and sociological reclamations in the South. Current Sociology, v. 54, n. 3, 2006, p. 357-380. 
SMITH, Linda Tuhiwai. Decolonizing Methodologies: Research and Indigenous Peoples. 2 ed. London: Zed Books, 2012.SOMERVILLE, Margaret; PERKINS, Tony. Singing the Coast. Camberra: Aboriginal Studies Press, 2010.

STEINMETZ, George (ed.). Sociology \& Empire: The Imperial Entanglements of a Discipline. Durham/London: Duke University Press, 2013.

STINCHCOMBE, Arthur L. Should sociologists forget their mothers and fathers? American Sociologist, v. 17, n. 1, 1982, p. 2-11.

SWINGEWOOD, Alan. A Short History of Sociological Thought. 3 ed. Basingstoke: Palgrave, 2000.

THAYER, Millie. Translations and refusals: resignifying meanings as feminist political practice. Feminist Studies, v. 36, n. 1,2010 , p. 200-230.

TITARENKO, Larissa. Post-Soviet sociology as a pattern of "another sociology". In: KALEKIN-FISHMAN, Devorah; DENNIS, Ann (eds.). The Shape of Sociology for the 215t Century: Tradition and Renewal. Los Angeles: Sage, 2012, p. 218-237.

TRIBE, Keith (ed.). Reading Weber. London/New York: Routledge, 1989.

WOLFF, Kurt H. (ed.). Georg Simmel, 1858-1918: A Collection of Essays, with Translations and a Bibliography. Columbus: Ohio State University Press, 1959.

YUNUPINGU, Galarrwuy (ed.). Our Land is Our Life. Brisbane: University of Queensland Press, 1997. 